\section{Public brawl over breast implants: round 3}

Plans by a US company to bring back silicone breast implants have rekindled bias accusations against National Cancer Institute researcher Louise Brinton, who heads the institute's ongoing study on implant safety. As the 13-year study enters its final stage, Brinton finds herself once again denying charges that she served as a consultant to lawyers who sued implant makers.

In 1998, a group of scientists criticized the study design in The Lancet before any results had been released. Although the scientists did not mention Brinton by name, they referred to a letter to the plaintiffs' lawyers, where she described the study as an "opportunity for women who may be suffering as a result of implants to be heard." Plans to recruit study subjects via plaintiffs' lawyers, they said, would introduce "major biases" into the study.

Brinton denies she had any such plans. All the patients were recruited through plastic surgery practices, she adds, but she wrote the letter in question to convince lawyers to allow their clients to enroll in the study. "We heard another study by the manufacturers had been sabotaged by lawyers telling their clients not to participate," she told Nature Medicine. "To this day, I do not have any presupposition that breast implants are associated with longterm adverse repercussions."

In this round of the dispute, Steven Milloy, who runs the website www.junkscience.com, indicted Brinton in a January 2003 Washington Times column

\section{SCID trials to remain on the 'bubble'}

Pending further data, retroviral gene therapy trials for the so-called 'bubble boy' disease should remain on hold, says a US National Institutes of Health (NIH) committee. The Food and Drug Administration (FDA) is expected to make a decision about the trials based on the committee's recommendations and those of its own advisory group, which is scheduled to meet 28 February.

The NIH's Recombinant DNA Advisory Committee (RAC) met in December, and again on 10 February, to review the adverse events in a French gene therapy trial for $X$ linked severe combined immunodeficiency disease (SCID). The FDA placed the trial on hold after two study participants developed leukemia.

After reviewing the clinical and molecular data, RAC members concluded that the occurrence of leukemia in the trial was not a random event, and that both cases resulted from the introduction of a mutation at or near the LMO2 gene.

Because a majority of children in the trial "had major clinical improvement," however, the committee continues to recommend gene transfer for patients who do not respond to stem-cell transplantation, or for whom no suitable stem cell donor can be identified.

It also concludes that there is not enough evidence to warrant suspending other trials with retroviral vectors, including those for non-X-linked SCID.

Apoorva Mandavilli, New YorK

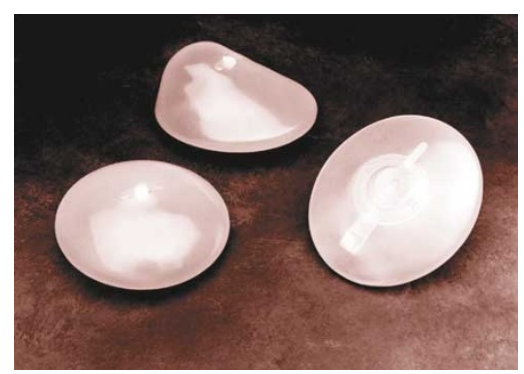

Accusations mount in implant debate

never served as a consultant.

From the beginning, the implant debate-and the barrage of lawsuits it triggered-drew attention to the quality of research used to both support and question implant safety. In 1992, the Food and Drug Administration (FDA) responded to implant complaints by pulling them off the market until manufacturers could perform thorough safety studies. As a result, there was little scientific data available to judge women's claims that their implants were making them sick.

Most of the subsequent research failed to find a direct connection between implants and systemic diseases like lupus. In 1999, an Institute of Medicine panel dismissed the link between implants and serious illness.

Women with implants-who were once suing manufacturers by the thousandstoday have trouble finding lawyers to take their cases. In 2001, a record 200,000 women in the United States had breast augmentation surgery. Most used saline, but in December 2002, Inamed Corporation asked the FDA for permission to begin selling silicone implants.

The FDA will have some new data to consider when it reviews that application. A 2001 study by the agency found a higher rate of fibromyalgia in women whose silicone had migrated out of the breast area. Initial results from Brinton's study suggest women with implants are not at greater risk of breast cancer, but have a statistically higher rate of lung and brain cancers than other plastic surgery patients.

Brinton says the increased cancer rates are "difficult to interpret," in part because the numbers are so small. NCI is continuing to collect data to further examine those findings and measure the risk of connective tissue disorders, which could take years to develop.

An NCI spokesman told Nature Medicine the agency supports Brinton's work and believes she is doing "the best science possible."

Tinker Ready, Boston 